Nyttige adresser og nettsteder blir også stort sett unyttige for nordmenn, ettersom alle bortsett fra $w w w$.clinicalevidence.com er danske adresser/telefonnumre.

Alt $i$ alt er dette en kjekk lommebok som akkurat som min lommebok, har hull og mangler som gjør at jeg ikke uten forbehold kan anbefale den til andre.

\section{Olav Sandstad}

Gastromedisinsk avdeling

Oslo universitetssykehus, Ullevål

\section{God dansk/svensk lærebok i intensivmedisin}

Larsson A, Rubertsson S.

Intensiv medicin

730 s, tab, ill. København: FADL's Forlag, 2008. Pris DKK 850

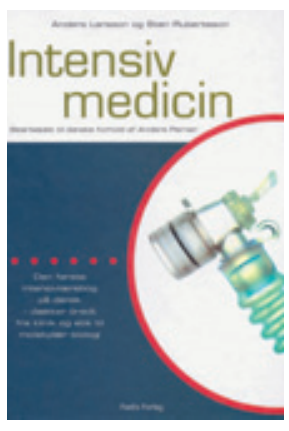

Dette er noe så sjeldent som en omfattende lærebok $\mathrm{i}$ intensivmedsin i nordisk (dansk) språkdrakt. Boken er en dansk oversettelse av Intensivvård som ble utgitt i 2005 med de samme hovedredaktører.

Den henvender seg til yngre leger med interesse for intensivmedisin (gjerne under spesialisering i relevant fagområde), men bør også være velegnet som oppslagsbok for intensivsykepleiere.

Innholdet er ganske omfattende og blir presentert i 57 kapitler. Hvert kapittel har en eller flere «originalforfattere» og så en dansk «referent». Først kommer 11 kapitler generelt om intensivmedisin/sykdomsmekanismer etc. Deretter følger kapitler om nevrointensivmedisin, respirasjonssvikt, gastrointestinale problemer, nyresvikt og infeksjoner. Kardiovaskulære problemer blir ikke omtalt samlet, men kommer dels i kapittel 15 (akutt kardiologi), kapittel 39 (sjokk) og kapittel 42 (hjerte-lunge-redning). Underlig nok er det et eget kapittel om monitorering av respirasjon, men ikke noe eget kapittel om sirkulasjonsmonitorering (dette finnes som et underkapittel i kapitletom sjokk).

Boken er velskrevet, lettlest og med en moderne, smakfull layout. Etter hvert kapittel finnes en sammenfatning i en uthevet «rute». Litteraturreferanser kommer samlet helt bakerst, inndelt etter kapitlene. Et kapittel: «Registrering og oppfølging av intensivbehandling» har ingen litteraturliste (uteglemt?). Av de kapitlene denne anmelderen leste grundig, var dette det svakeste. Innen intensivmedisin er det når det gjelder oppfølging av overlevere etter intensivbehandling, at de nordiske land og forfattere virkelig har gjort seg internasjonalt kjent. Beskrivelsen av de ulike intensivskår er overfladisk og konsentrerer seg vesentlig om APACHE II. Ingen av de gode studiene som viser resultat etter langtidsoppfølging fra Norge, Finland og Sverige, blir nevnt eller diskutert.

Det er positivt at det er tatt med noen generelle kapitler om cellebiologi, celledød, iskemi, inflammasjon etc.

Boken kan anbefales som en godt oppdatert oversikt til intensivmedisinsk interesserte leger, kanskje spesielt til dem som senere vil få ansvar for hele eller deler av slik behandling (anestesileger, kirurger og medisinere under utdanning).

\section{Hans Flaatten}

Kirurgisk serviceklinikk

Haukeland universitetssykehus

\section{Informativt og nyttig om hjerneslag}

Bornstein NM, red.

Stroke

Practical guide for clinicians. 202 s, tab, ill.

Basel: Karger, 2009. Pris CHF 198

ISBN 978-3-8055-9099-0

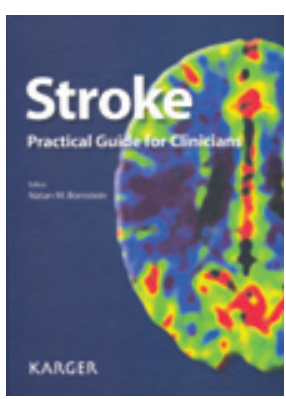

Bornstein og medforfattere har på litt over 200 sider gitt oss en oppdatert og velskrevet lærebok for klinikere som arbeider med hjerneslagpasienter. Hensikten er å gi leseren basiskunnskap om cerebrovaskulær patofysiologi, diagnostikk og behandling. Boken passer ypperlig for nykommere innen faget, men også som en oppfriskning av kunnskap hos den erfarne kliniker, da publikasjoner til og med 2008 er tatt med.

I atskilte kapitler gir anerkjente spesialister innen cerebrovaskulær medisin en grundig og oppdatert beskrivelse av sine «hjertebarn». Formen i de ulike kapitlene varierer og blir derfor mer eller mindre leservennlige. Men gjennomgående er fremstillingen lettlest, med fine illustrasjoner og tabeller.

Medikamentelle tiltak er godt ivaretatt. Primærprofylakse og sekundærprofylakse er meget grundig og godt beskrevet med oppdatert litteratur. For norske lesere vil det sannsynligvis være mer naturlig å følge de norske retningslinjene som er under bearbeiding, enn de amerikanske som det $\mathrm{i}$ hovedsak refereres til.
Praktikeren og klinikeren vil nok savne en mer inngående beskrivelse av akutt behandling. Behandling av akutte komplikasjoner i akuttfasen og håndteringen av progredierende symptomer er ikke nevnt, heller ikke nevrokirurgiens plass i akuttbehandlingen. Prognostisering og vurdering av rehabiliteringspotensial er heller ikke nevnt og modeller for oppfølging og opptrening av slagpasienter etter utskrivning er også sparsomt beskrevet. Jeg savner også en beskrivelse av verktøy som benyttes for monitorering av pasienten i akuttfasen og kartlegging av funksjon.

Tyngdepunktet er med andre ord diagnostikk med en bred beskrivelse av nevroradiologi og ultralyd, som nok er begynnelsen på en ny æra hvor de kliniske konsekvensene så langt ikke er klarlagt. Det praktiske arbeidet med pasientene i en slagenhet er viet mindre plass.

Boken gir en god og interessant introduksjon til viktige ansvarsområder for en kliniker, men må suppleres med annen litteratur for å ivareta andre viktige aspekter av hjerneslagsykdommen, hvor det er viktig at legen også er på banen og engasjerer seg.

\section{Medikamentell kreftbehandling - biologi og klinikk}

Airley R.

Cancer chemotherapy

Basic science to the clinic. $341 \mathrm{~s}$, tab, ill.

Chichester: Wiley-Blackwell, 2009. Pris GBP 25 ISBN 978-0-470-09255-2

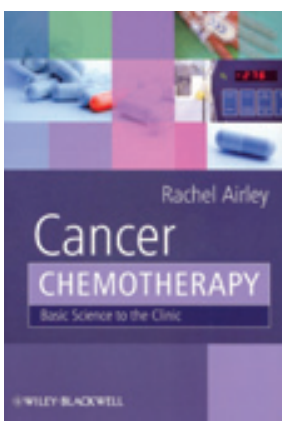

Ikkje skal eg vere påståeleg, men det kan da ikkje vere mange andre medisinske spesialitetar der ny basalbiologisk kunnskap så raskt kjem til direkte nytte i sjukdomsdiagnostikk og spesielt pasientbehandling som innan kreftfaget. Denne lettlesne læreboka for studentar innan farmasi, medisin og biomedisinske fag, skriven av universitetslærar i farmakologi, har som målsetting å vise korleis tumorretta medikament, både tradisjonelt cytotoksiske og nye biologiske substansar, blir brukt i moderne kreftbehandling. Den oppdaterte framstillinga omfattar også molekylærbiologiske mekanismar involverte i utvikling og progrediering av maligne sjukdommar samt strategiar for 